\title{
Extracellular acid-base regulation during short-term hypercapnia is effective in a shallow-water crab, but ineffective in a deep-sea crab
}

\author{
Eric F. Pane* ${ }^{*}$ James P. Barry \\ Monterey Bay Aquarium Research Institute, 7700 Sandholdt Road, Moss Landing, California 95039, USA
}

\begin{abstract}
Rising levels of atmospheric carbon dioxide could be curbed by large-scale sequestration of $\mathrm{CO}_{2}$ in the deep sea. Such a solution requires prior assessment of the impact of hypercapnic, acidic seawater on deep-sea fauna. Laboratory studies were conducted to assess the short-term hypercapnic tolerance of the deep-sea Tanner crab Chionoecetes tanneri, collected from $1000 \mathrm{~m}$ depth in Monterey Canyon off the coast of central California, USA. Hemolymph acidbase parameters were monitored over $24 \mathrm{~h}$ of exposure to seawater equilibrated with $\sim 1 \% \mathrm{CO}_{2}$ (seawater $\mathrm{P}_{\mathrm{CO}_{2}}$ $\sim 6$ torr or $0.8 \mathrm{kPa}, \mathrm{pH} 7.1$ ), and compared with those of the shallow-living Dungeness crab Cancer magister. Short-term hypercapnia-induced acidosis in the hemolymph of Chionoecetes tanneri was almost uncompensated, with a net $24 \mathrm{~h} \mathrm{pH}$ reduction of 0.32 units and a net bicarbonate accumulation of only $3 \mathrm{mM}$. Under simultaneous hypercapnia and hypoxia, short-term extracellular acidosis in Chionoecetes tanneri was completely uncompensated. In contrast, Cancer magister fully recovered its hemolymph $\mathrm{pH}$ over $24 \mathrm{~h}$ of hypercapnic exposure by net accumulation of $12 \mathrm{mM}$ bicarbonate from the surrounding medium. The data support the hypothesis that deep-sea animals, which are adapted to a stable environment and exhibit reduced metabolic rates, lack the short-term acid-base regulatory capacity to cope with the acute hypercapnic stress that would accompany large-scale $\mathrm{CO}_{2}$ sequestration. Additionally, the data indicate that sequestration in oxygen-poor areas of the ocean would be even more detrimental to deep-sea fauna.
\end{abstract}

KEY WORDS: $\mathrm{CO}_{2} \cdot$ Deep sea $\cdot$ Physiology $\cdot$ Decapod crustacea $\cdot$ Acid-base regulation $\cdot$ Chionoecetes tanneri . Cancer magister

Resale or republication not permitted without written consent of the publisher

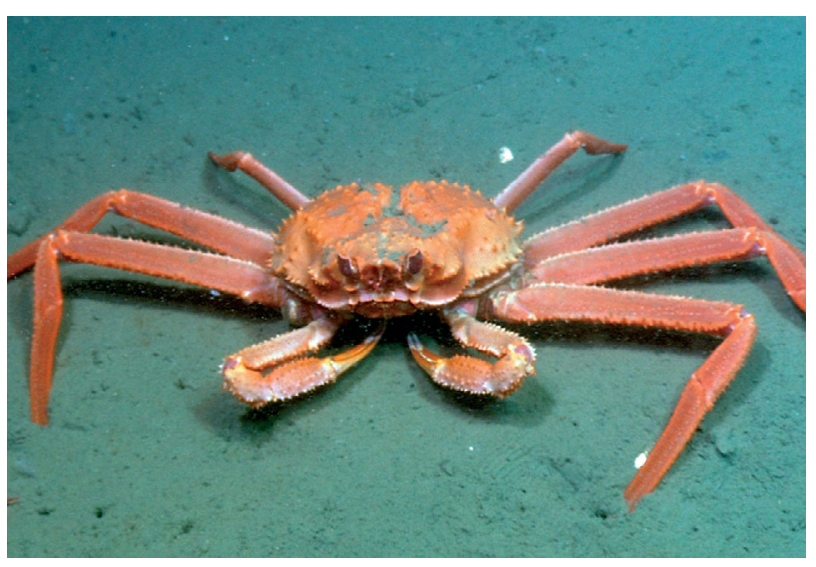

The ocean's large-scale absorption, as well as possible future anthropogenic sequestration of atmospheric $\mathrm{CO}_{2}$, will result in long-term acidification of the water. The deep-sea crab Chionoecetes tanneri (collected from Monterey Canyon at $1000 \mathrm{~m}$ depth) is unable to regulate extracellular $\mathrm{pH}$ during short-term $\mathrm{CO}_{2}$ exposure. The results of Pane \& Barry support the hypothesis that hypercapnia will have a profound physiological impact on deep-sea organisms.

Photo: MBARI (2006)

\section{INTRODUCTION}

Large-scale sequestration of carbon dioxide in the deep sea (Marchetti 1977, 1979), as a means of reducing atmospheric $\mathrm{CO}_{2}$ emissions and mitigating greenhouse-gas-induced climate change, remains a potential solution to the problem of escalating atmospheric $\mathrm{CO}_{2}$ levels. Accordingly, the possibility of large-scale anthropogenic inputs of $\mathrm{CO}_{2}$ into the deep-sea has created intriguing and pressing research questions. 
Because the physiology of deep-sea animals is so poorly understood, putative deep-sea $\mathrm{CO}_{2}$ sequestration must be approached with caution (Seibel \& Walsh 2001, Portner et al. 2004). While in situ microcosmic $\mathrm{CO}_{2}$ release studies at depth have been conducted (Brewer et al. 2000, Tamburri et al. 2000, Barry et al. 2004), the direct physiological impacts of hypercapnia, and the acid-base regulatory capacities of deep-sea animals, have yet to be systematically investigated under laboratory conditions.

The general hypothesis that deep-sea animal acidbase regulatory capacity will be poorly adaptive to hypercapnic exposure rests on 2 basic principles. The first is the trend toward hypometabolism with depth in pelagic, typically visual, animals (Seibel et al. 1997). The theory holds that limited light with depth reduces visual predation pressure and selects for reduced locomotory ability and metabolic capacity (Childress et al. 1990, Childress \& Seibel 1998). Although this theory applies predominantly to pelagic animals, deep-sea benthic animals (including crustaceans) also exhibit metabolic rates typically an order of magnitude lower than their shallow-living counterparts (Childress et al. 1990, Henry et al. 1990). While this phenomenon in deep-sea benthic crustaceans may simply be a function of very low temperatures at depth in areas of steep thermal gradient (Childress et al. 1990), these reduced metabolic rates observed in deep-sea benthic crustaceans may still be ecologically relevant (disadvantageous) in the context of hypercapnic exposure.

Secondly, acid-base regulatory capacity of deep-sea fauna may be maladaptive to hypercapnia due to the natural invariance of their chemical environment. The deep sea has been characterized for several thousands of years by stable physico-chemical water parameters (Gage \& Tyler 1991, Kennett \& Ingram 1995, Portner et al. 2004). Unlike some shallow dwelling aquatic animals who have evolved effective acid-base regulatory capabilities to combat seasonal, or even daily, fluctuations in water $\mathrm{pH}$, oxygen and $\mathrm{CO}_{2}$ concentration, or temperature, deep-sea animals theoretically should not possess such well-developed acid-base regulatory capacity (Childress \& Seibel 1998, Seibel \& Walsh 2001).

In this study, we took a comparative physiological approach in testing the hypothesis that deep-sea animals have limited acid-base regulatory capacity. We investigated the response of a deep-sea benthic decapod crab, Chionoecetes tanneri (Grooved Tanner crab), to acute laboratory-based hypercapnic exposure, and compared it to that of a shallow-living decapod crab, Cancer magister (Dungeness crab).

Chionoecetes tanneri, of the brachyuran family Majidae, is the dominant decapod crab of the Monterey Canyon seafloor at $1000 \mathrm{~m}$, and the only decapod spe- cies occurring at densities compatible with remoteoperated vehicle collection at depth. It is a sluggish species, large enough to facilitate repetitive blood sampling, yet easily kept in the laboratory with very low feeding requirements. Cancer magister is a large, highly abundant crab of the family Cancridae, common to northeastern Pacific coastal waters. Though predominantly subtidal and found mostly at depths to $90 \mathrm{~m}$, shoreward spring migrations bring them into shallower water margins of sandy beaches and estuaries (Morris et al. 1980, Airriess \& McMahon 1994). Hence, Cancer magister may experience changes in water salinity, partial pressures of oxygen $\left(\mathrm{P}_{\mathrm{O}_{2}}\right)$, and carbon dioxide $\left(\mathrm{P}_{\mathrm{CO}_{2}}\right)$, and $\mathrm{pH}$ as frequently as each tidal cycle (Airriess \& McMahon 1994). Our choice of Cancer magister as an experimental species was also influenced by its representation in the existing acidbase, respiratory, and circulatory literature (e.g. Johansen et al. 1970, Airriess \& McMahon 1994).

Additionally, we explored the influence of oxygen availability on the response of the deep-sea Tanner crab to hypercapnia. Chionoecetes tanneri was collected from the Monterey Canyon at depths of $\sim 1000 \mathrm{~m}$ (Fig. 1), within the oxygen minimum zone (OMZ) typical of eastern Pacific waters and the Monterey Canyon (Fig. 2). The OMZ is the ocean zone of lowest oxygen saturation created by the processes of biotic oxygen consumption and ocean circulation (Wyrtki 1962). In the eastern Pacific it typically occurs between 500 and $1000 \mathrm{~m}$. Accordingly, we tested the response of Tanner crabs to hypercapnia when held in both low oxygen (simulating OMZ levels) and high oxygen (fully saturated seawater).

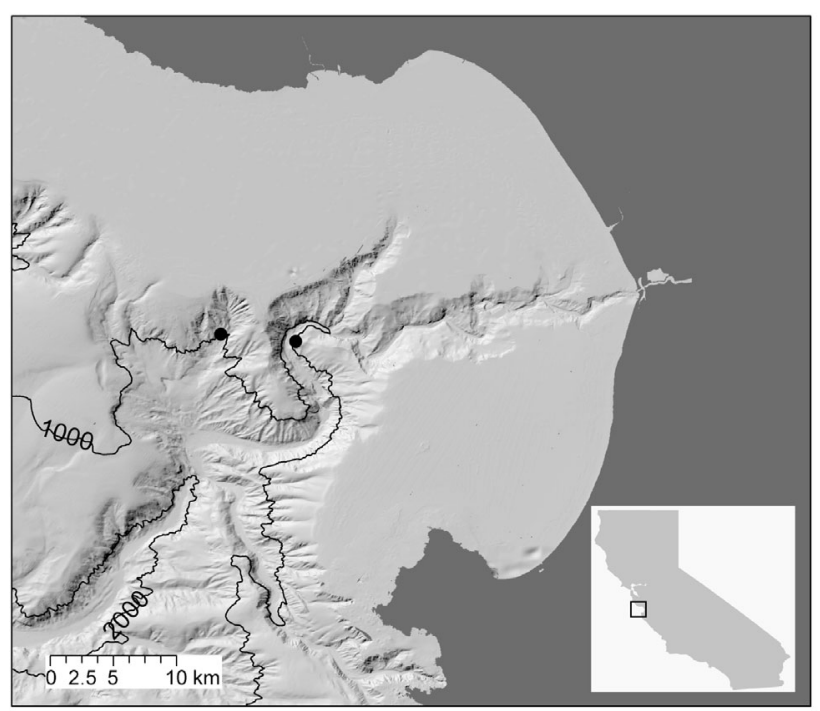

Fig. 1. Locations of ROV 'Ventana' dive sites at $\sim 1000 \mathrm{~m}$ in Monterey Canyon $(\bullet)$ for collection of the deep-sea decapod Grooved Tanner crab Chionoecetes tanneri 


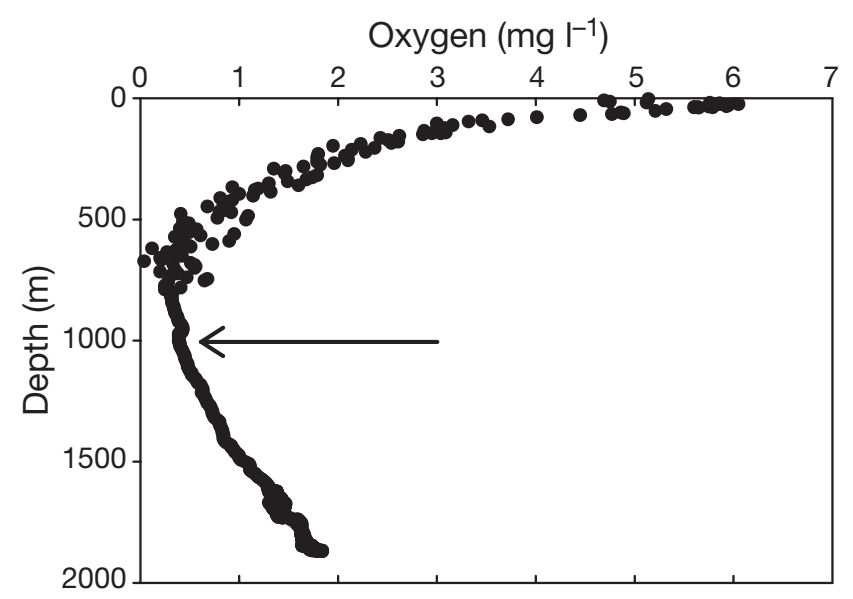

Fig. 2. Oxygen profile in Monterey Canyon, showing the oxygen minimum zone (OMZ) between 600 and $1200 \mathrm{~m}$. Arrow: sampling depth for Chionoecetes tanneri

The level of hypercapnia used, $\left(\sim 1 \% \mathrm{CO}_{2}\right)$ has frequently been employed for both invertebrates and vertebrates from freshwater and marine systems (Cameron 1978, Truchot 1979, Toews et al. 1983, Claiborne \& Heisler 1986, Langenbuch \& Portner 2002, Edwards et al. 2005). A one-unit reduction in water $\mathrm{pH}$ typically occurs with this level of hypercapnia, and the exposure requires a competent acid-base regulatory capacity to offset the initial extracellular acidosis caused by exposure to hypercapnic seawater.

\section{MATERIALS AND METHODS}

Crab collection and holding. Grooved Tanner crabs Chionoecetes tanneri of both sexes (200 to $600 \mathrm{~g}$ ) were collected by remote-operated vehicle (ROV 'Ventana') from depths of 950 to $1050 \mathrm{~m}$ from the seafloor of Monterey Canyon (Fig. 1). The ROV 'Ventana' was operated from the RV 'Point Lobos', under the stewardship of the Monterey Bay Aquarium Research Institute.

Once retrieved from depth, crabs were held aboard ship in $2^{\circ} \mathrm{C}$ seawater until transfer to the laboratory. Total time from collection to laboratory transfer was 3 to $5 \mathrm{~h}$ and survival was typically $75 \%$ during this process.

In the laboratory, crabs were held in 3 cubic 1101 tanks under flow-through conditions with oxygen regulated via a computer-controlled gas-regulated aquarium system. In brief, oxygen was controlled using a combination of sensors (Aanderra oxygen optodes) and gas contactors through which mixtures of nitrogen and oxygen were used to maintain dissolved gases near prescribed setpoints for oxygen. Temperature was also regulated. The total volume of the recirculating system was 1000 l. Flow-through was achieved by addition of $0.251 \mathrm{~min}^{-1}$ to each tank from a common reservoir of seawater equilibrated to a set oxygen level by the processes described above.

With the exception of hydrostatic pressure, in situ $(\sim 1000 \mathrm{~m})$ seawater conditions were replicated by holding all crabs in constant darkness in water of $3 \pm$ $1^{\circ} \mathrm{C}$, a pH of $7.85 \pm 0.10$, and a salinity of 34 ppt. All holding and experimentation was conducted at surface pressure. While we recognize the inconsistency of holding animals collected from $1000 \mathrm{~m}$ at surface pressure, the technical challenges of in vivo work with macrofauna at high hydrostatic pressure in a laboratory setting are formidable. We therefore weigh any potential depth-related changes in physiological function against the following observations regarding Chionoecetes tanneri held at surface pressure: (1) once acclimated to the laboratory, survival is extremely high, with crabs surviving $>18$ mo (cf. Henry et al. 1990); (2) crabs molt in the laboratory; and (3) once acclimated, post-branchial hemolymph $\mathrm{pH}$ of resting crabs consistently falls within a tight range (7.9 to 8.1) consistent with alphastat regulation in aquatic animals held at $3^{\circ} \mathrm{C}$ (Cameron 1986).

The oxygen concentration of the seawater was set to either $90 \pm 5 \%$ saturation ('High', $350 \mu \mathrm{M}$ ), or $10 \pm$ $5 \%$ saturation ('Low', $\sim 40 \mu \mathrm{M}$ ). The lower $\mathrm{O}_{2}$ treatment mimicked in situ oxygen levels typical of the oxygen minimum zone at depths between roughly 600 and $1200 \mathrm{~m}$ off the California coast and within the Monterey Canyon (Childress 1995; our Fig. 2).

Pacific Dungeness crabs Cancer magister of both sexes (500 to $1000 \mathrm{~g}$ ) were purchased locally (Moss Landing, CA) from commercial fisherman using baited traps at 30 to $40 \mathrm{~m}$. Dungeness crabs were held in the laboratory in flowing seawater of $10 \pm 1^{\circ} \mathrm{C}$, a pH of $7.9 \pm 0.1$, a salinity of $34 \mathrm{ppt}$, and an oxygen saturation of $90 \pm 5 \%$, under a 12:12 h light:dark photoperiod.

All crabs introduced to the laboratory were allowed a minimum of $3 \mathrm{wk}$ to acclimate before experimentation. Both species of crab were fed twice weekly to satiation with chopped squid; food was withheld $72 \mathrm{~h}$ prior to experimentation, and only hard-shelled intermolt animals were used in experiments.

In vitro experiments. The non-bicarbonate buffering capacity $(\beta)$ of sera was determined for Cancer magister and for Chionoecetes tanneri held in both low and high oxygen. In all experimentations, post-branchial hemolymph was accessed by drilling a small (1 $\mathrm{mm}$ ) hole in the dorsal carapace directly above the heart. A ring of cyanoacrylate glue was applied around the hole and a $1 \mathrm{~cm}$ square piece of dental dam was glued into place (Forgue et al. 1992). Crabs were allowed a minimum $72 \mathrm{~h}$ recovery period prior to experimentation. All hemolymph was drawn anaerobically into ice-cold 
gas-tight Hamilton syringes rinsed with Crab Ringer comprised of (in mM) NaCl (460), $\mathrm{KCl}$ (10), $\mathrm{CaCl}_{2}(20)$, $\mathrm{MgCl}_{2}$ (9.5), and $\mathrm{H}_{3} \mathrm{BO}_{3}$ (3), $\mathrm{pH} 7.80$ (Lang \& Gainer 1969).

For tonometric analysis, hemolymph was drawn and allowed to clot on ice for $10 \mathrm{~min}$. Hemolymph was then centrifuged aerobically at $4000 \times g$ at $3^{\circ} \mathrm{C}$ for $3 \mathrm{~min}$, producing separated, rather than true, serum (Davenport 1974). Separated serum was then added $(\sim 150 \mu \mathrm{l})$ to round-bottom flasks and equilibrated with humidified gas mixtures of $\mathrm{CO}_{2}$ and nitrogen from preanalyzed cylinders (Airgas). Sera were equilibrated for $90 \mathrm{~min}$ in a shaking water bath at the appropriate temperature $\left(10^{\circ} \mathrm{C}\right.$ for Cancer magister serum and $3.5^{\circ} \mathrm{C}$ for Chionoecetes tanneri serum).

After equilibration, samples were drawn into gastight syringes and $\mathrm{pH}$ was measured using a microelectrode and in-line reference electrode (Microelectrodes) thermostatted to the appropriate temperature and coupled to an Accumet (Fisher Scientific) $\mathrm{pH}$ meter. Total $\mathrm{CO}_{2}\left(\mathrm{C}_{\mathrm{CO}_{2}}\right)$ was measured by non-dispersive infrared analysis (LI-COR model 6262), following acidification (5\% phosphoric acid) of serum and introduction of stripped gas into an infrared analyzer (Friederich et al. 2002). pH was standardized with Radiometer Analytical precision buffers adjusted to the ionic strength of crab serum ( 1050 mOsm), while $\mathrm{C}_{\mathrm{CO}_{2}}$ was standardized with $\mathrm{NaCO}_{3}$ (Sigma-Aldrich) dried for $4 \mathrm{~h}$ at $250^{\circ} \mathrm{C}$ prior to making carbonate standards.

Serum $\mathrm{CO}_{2}$ tension $\left(\mathrm{P}_{\mathrm{aCO}_{2}}\right)$ and serum $\left[\mathrm{HCO}_{3}{ }^{-}\right]$, based on measured $\mathrm{pH}$ and $\mathrm{C}_{\mathrm{CO}_{2}}$, were calculated by rearrangement of the Henderson-Hasselbach equation with values for $\mathrm{CO}_{2}$ solubility $\left(\alpha \mathrm{CO}_{2}\right)$ and apparent $\mathrm{pK}\left(\mathrm{pK}^{\prime}\right)$ at the appropriate temperature taken from Boutilier et al. (1984) and Truchot (1976).

$\beta \mathrm{s}$ were derived from linear regression of $\mathrm{pH}$-bicarbonate plots for each species and oxygen treatment (Truchot 1979, Cameron 1985, 1986). These speciesand oxygen-specific slopes appear on the appropriate Davenport diagrams as dashed lines (see Fig. 4).

In vivo experiments. Crabs were placed in individual 12 (Chionoecetes tanneri) or 201 (Cancer magister) darkened boxes with no head space, moderately tightfitting lids, and a water flow of approximately $50 \mathrm{ml}$ $\mathrm{min}^{-1}$. All Cancer magister experiments were run at $10^{\circ} \mathrm{C}$, and all Chionoecetes tanneri exposures were run at $3.5^{\circ} \mathrm{C}$. Cancer magister and Chionoecetes tanneri in the high $\mathrm{O}_{2}$ treatment were exposed to seawater equilibrated via an exchange column (Membrana) to a gas mixture of $1 \% \mathrm{CO}_{2}, 20 \% \mathrm{O}_{2}$ ('high $\mathrm{O}_{2}{ }^{\prime}$ ), and balance $\mathrm{N}_{2}$ delivered from a premixed, calibrated gas cylinder (Airgas). Chionoecetes tanneri in the low $\mathrm{O}_{2}$ treatment were exposed in a similar fashion to seawater equilibrated with a cylinder comprising $1 \% \mathrm{CO}_{2}, 3 \% \mathrm{O}_{2}$ ('low $\mathrm{O}_{2}{ }^{\prime}$ ), and balance $\mathrm{N}_{2}$. Nominal levels of oxygen saturation in seawater equilibrated with the 2 gas mixtures were approximately 95 and $14 \%$, respectively. Water $\mathrm{pH}$ was measured at the appropriate temperature using a Radiometer immersion electrode calibrated with Radiometer Analytical precision pH buffers adjusted to the ionic strength of seawater. Mean water $\mathrm{pH}$ (from all 3 treatments) at $24 \mathrm{~h}$ of hypercapnic exposure was $7.08 \pm 0.01$ ( $\mathrm{SE}, \mathrm{n}=18$ measurement).

Post-branchial hemolymph was sampled immediately prior to onset of hypercapnic exposure, and then at $25 \mathrm{~min}, 50 \mathrm{~min}, 75 \mathrm{~min}, 2.5 \mathrm{~h}, 4.25 \mathrm{~h}$, and $24 \mathrm{~h}$ of hypercapnia. Hemolymph pH was measured as described above, while $\mathrm{C}_{\mathrm{CO}_{2}}$ was measured as described above on true serum obtained from anaerobic centrifugation $(12000 \times g$ for $1 \mathrm{~min})$. Separate aliquots of separated serum (see above) were immediately snap-frozen in liquid $\mathrm{N}_{2}$ for later analysis of protein concentration, and deproteinized in 2 volumes of ice-cold $6 \%$ perchloric acid prior to snap-freezing for later analysis of serum lactate concentration.

Hemolymph dioxide tension $\left(\mathrm{P}_{\mathrm{CO}_{2}}\right)$ and $\left[\mathrm{HCO}_{3}{ }^{-}\right]$, based on measured $\mathrm{pH}$ and $\mathrm{C}_{\mathrm{CO}_{2}}$, were calculated as described above. Serum protein concentration was analyzed by the method of Bradford (1976) using reagent and BSA standards from Pierce Biotechnology. Serum lactate was measured with a commercial kit (reagents and standards) from Trinity Biotech.

Statistics. All measured values are presented as mean \pm 1 SEM ( $n=$ number of crabs). Data were tested for normality (Shapiro-Wilk test) and homogeneity of variance (Levene test) prior to statistical treatment. Data meeting these assumptions were analyzed for significant differences using a 1-way ANOVA followed by a Bonferroni's post-hoc multiple comparison test. Data not meeting parametric assumptions were compared using a Kruskal-Wallis test followed by multiple comparison testing according to the method of Dunn (1964), as described in Zar (1984). Statistical significance in all cases was accepted at the $\mathrm{p}<0.05$ level.

\section{RESULTS}

Over $24 \mathrm{~h}$ of hypercapnic exposure, Cancer magister exhibited almost complete extracellular acid-base regulation despite hemolymph $\mathrm{pH}$ dropping more quickly and more sharply over the first hour of hypercapnia than in either Chionoecetes tanneri treatment (Fig. 3A). Compensation of hemolymph pH in Cancer magister began at $75 \mathrm{~min}$ and continued over the remainder of the exposure period, resulting in almost complete compensation by $24 \mathrm{~h}$. In neither Chionoecetes tanneri treatment was any $\mathrm{pH}$ compensation observed over the first $4 \mathrm{~h}$. Only at $24 \mathrm{~h}$ was pH slightly recovered in Chionoecetes tanneri acclimated to both 

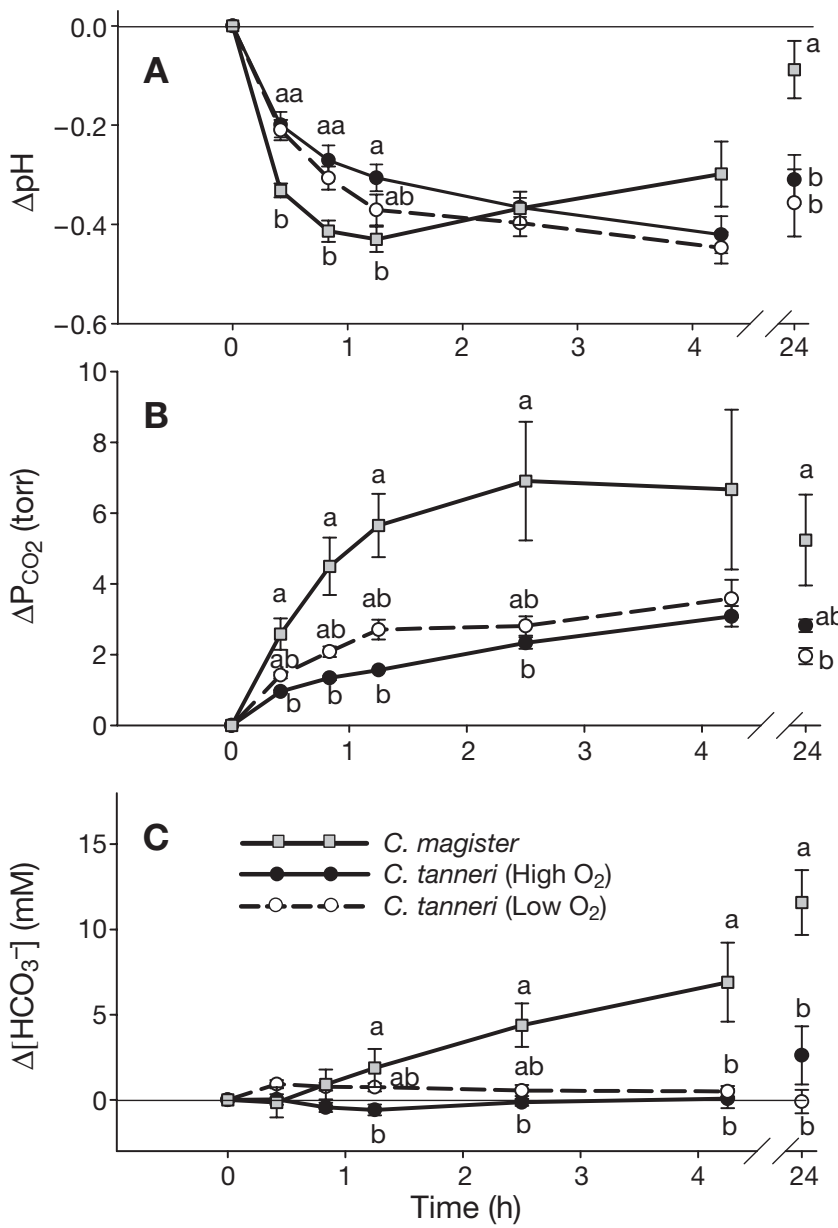

Fig. 3. Cancer magister and Chionoecetes tanneri. Delta profiles of (A) $\mathrm{pH},(\mathrm{B}) \mathrm{P}_{\mathrm{CO}_{2}}$ and (C) $\left[\mathrm{HCO}_{3}{ }^{-}\right]$for post-branchial hemolymph acid-base parameters during a $24 \mathrm{~h}$ hypercapnic $\left(1 \% \mathrm{CO}_{2}\right)$ exposure. Data are mean $\pm \mathrm{SE}$. Treatment means not sharing the same letter are significantly different

high and low oxygen (Fig. 3A). The resultant net reductions in hemolymph $\mathrm{pH}$ over the $24 \mathrm{~h}$ period were 0.08 (C. magister), 0.32 (Chionoecetes tanneri, high $\mathrm{O}_{2}$ ), and 0.38 (Chionoecetes tanneri, low $\mathrm{O}_{2}$ ) units, and the net hemolymph $\mathrm{pH}$ reduction at $24 \mathrm{~h}$ in Cancer magister was significantly less than that of either treatment of Chionoecetes tanneri (Fig. 3A).

The change in hemolymph $\mathrm{P}_{\mathrm{CO}_{2}}\left(\Delta \mathrm{P}_{\mathrm{CO}_{2}}\right)$ profile for Cancer magister was consistently higher than those of both Chionoecetes tanneri treatments throughout the hypercapnic exposure (Fig. 3B). Internalization of $\mathrm{CO}_{2}$ in the 2 Chionoecetes tanneri treatments was similar throughout the exposure period.

A substantial increase $(12 \mathrm{mM})$ in the bicarbonate concentration of Cancer magister hemolymph occurred over the course of $24 \mathrm{~h}$ of hypercapnia. In contrast, bicarbonate gains in Chionoecetes tanneri were modest $(3 \mathrm{mM})$ in the high oxygen treatment and non- existent in the low oxygen treatment (Fig. 3C). In neither Chionoecetes tanneri treatment was any appreciable gain in hemolymph bicarbonate observed over the first $4 \mathrm{~h}$.

Viewed on a pH-bicarbonate (Davenport) diagram, the overall pattern of hypercapnic-induced acidotic recovery in Cancer magister was consistent with that of competent aquatic acid-base regulators. In all 3 treatments, the first hour of hypercapnic exposure resulted in titration of hemolymph blood in an acidic direction, roughly down the non-bicarbonate buffering (B) line and consistent with $\mathrm{CO}_{2}$-derived respiratory acidoses (Fig. 4). From 1 to 4 h, hemolymph acid-base status in Cancer magister followed a typical pattern of metabolic compensation of respiratory acidosis, consistent with large gains in hemolymph bicarbonate concentration and movement in an alkalotic direction roughly along the 8 torr $\mathrm{P}_{\mathrm{CO}_{2}}$ isopleth (Fig. $4 \mathrm{~A}$ ).

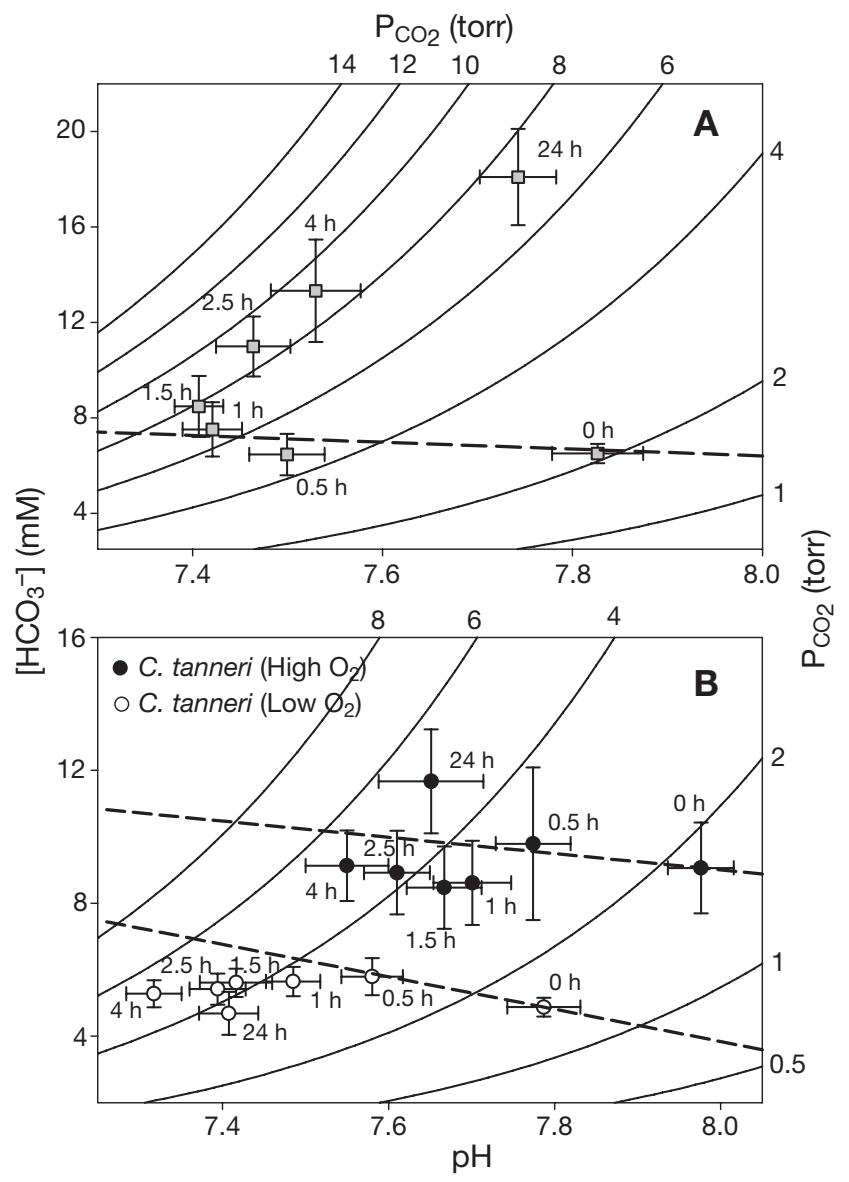

Fig. 4. (A) Cancer magister and (B) Chionoecetes tanneri. pHbicarbonate (Davenport) diagrams showing the time course of post-branchial hemolymph acid-base compensation during a $24 \mathrm{~h}$ hypercapnic $\left(1 \% \mathrm{CO}_{2}\right)$ exposure. Data are mean $\pm \mathrm{SE}$. Solid curved lines are $\mathrm{CO}_{2}$ isopleths. Straight dashed lines are serum non-bicarbonate buffer $(\beta)$ lines determined in vitro (see text for details) 


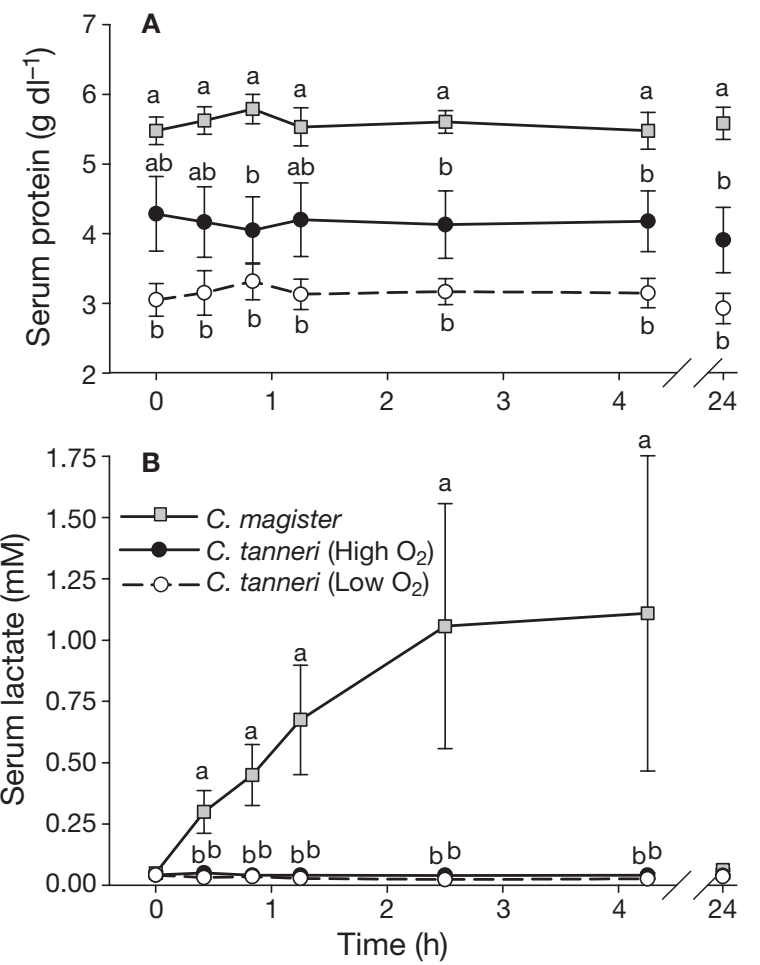

Fig. 5. Cancer magister and Chionoecetes tanneri. Time course of (A) serum protein and (B) serum lactate during a $24 \mathrm{~h}$ hypercapnic $\left(1 \% \mathrm{CO}_{2}\right)$ exposure. Data are mean $\pm \mathrm{SE}$. Treatment means not sharing the same letter are significantly different

In contrast, the acid-base variables for Chionoecetes tanneri held in low oxygen remained below the nonbicarbonate buffering $(\beta)$ line at all time points after $1 \mathrm{~h}$. This indicates a slight metabolic acidosis, which compounds the uncompensated respiratory acidosis observed in this treatment (Fig. 4B).

The serum protein concentration of Cancer magister was significantly higher than measured for Chionoecetes tanneri acclimated to low $\mathrm{O}_{2}$, both prior to the onset of hypercapnia and throughout the exposure (Fig. 5A). Additionally, under hypercapnia, serum protein levels in Cancer magister from $2.5 \mathrm{~h}$ onward were significantly greater than those measured in Chionoecetes tanneri acclimated to high oxygen (Fig. 5A).

Serum lactate in Cancer magister increased dramatically ( 25-fold) during the first $4.25 \mathrm{~h}$ of hypercapnia, only to return to baseline levels by $24 \mathrm{~h}$ (Fig. 5B). Conversely, serum lactate in Chionoecetes tanneri was unaffected by hypercapnia (Fig. 5B).

\section{DISCUSSION}

The deep-sea Tanner crab Chionoecetes tanneri did not regulate extracellular acid-base status during short-term (24 h) hypercapnic exposure. Compared to the near-complete extracellular compensatory response of the Dungeness crab Cancer magister, the Tanner crab response to hypercapnia was ineffective (in high $\mathrm{O}_{2}$ ) or non-existent (in low $\mathrm{O}_{2}$ ) over $24 \mathrm{~h}$ (Figs. 3 $\& 4)$. Our results indirectly support the hypothesis of Seibel \& Walsh (2001) that deep-sea animals exchange ions at the gills more slowly than their shallow-living counterparts, and are consistent with a general pattern of reduced rates of key metabolic and enzymatic processes in deep-sea decapod crabs, compared to shallow-living species (Henry et al. 1990, Walsh \& Henry 1990). Bicarbonate acquisition, the primary means of $\mathrm{pH}$ compensation in aquatic animals, was not observed in Tanner crabs acclimated to low oxygen, suggesting a marked reduction (or delay) in ion exchange.

In contrast, rapid, hypercapnic-induced extracellular bicarbonate acquisition (a net gain of $12 \mathrm{mM}$ over $24 \mathrm{~h}$; Fig. 3B) observed in Dungeness crabs fits the pattern observed in another strong acid-base regulator, the marine shore crab Carcinus maenas (Truchot 1979, 1984). It should be noted that the current work with Cancer magister $\left(\right.$ at $\left.10^{\circ} \mathrm{C}\right)$ and the work by Truchot $(1979,1984)$ with Carcinus maenas (at $16^{\circ} \mathrm{C}$ ) were conducted at substantially higher temperatures than the hypercapnic experiments with Chionoecetes tanneri $\left(3^{\circ} \mathrm{C}\right)$. In Carcinus maenas exposed to $\sim 1 \% \mathrm{CO}_{2}$ at $16^{\circ} \mathrm{C}$, relevant net transfers of acid-base equivalents across the branchial epithelium were accomplished in 8 to $10 \mathrm{~h}$. The possibility remains, therefore, that the adaptive extracellular response of Chionoecetes tanneri to hypercapnia may actually occur appropriately, just over a longer time period than $24 \mathrm{~h}$.

The discrepancy in hemolymph $\Delta \mathrm{P}_{\mathrm{CO}_{2}}$ profiles (Fig. 3B) during hypercapnic exposure (with Cancer magister internalizing more $\mathrm{CO}_{2}$ than the 2 Chionoecetes tanneri treatments) is at odds with the common notion that $\mathrm{CO}_{2}$ equilibrates rapidly among the external medium, the extracellular fluid, and the intracellular compartment. A simple explanation may involve transitory experimental variations in water $\mathrm{CO}_{2}$ tensions caused by variable gas exchange with the equilibration columns employed. While this would easily explain differences occurring in the first $4 \mathrm{~h}$ of hypercapnic exposure, $24 \mathrm{~h}$ water $\mathrm{pHs}$ were very similar among the 3 treatments, suggesting that the water $\mathrm{CO}_{2}$ partial pressures were also very similar at $24 \mathrm{~h}$. Yet the hemolymph $\Delta \mathrm{P}_{\mathrm{CO}_{2}}$ value in Cancer magister remained greater than those of the Tanner crabs. Cameron (1986) describes in detail the disequilibrium conditions of invertebrate blood with respect to $\mathrm{CO}_{2}$ internalization and excretion, concluding that $\mathrm{CO}_{2}$ in invertebrate blood most likely never reaches equilibrium conditions. Such an occurrence would certainly confound assumptions and discussions of $\mathrm{CO}_{2}$ equilibrium dur- 
ing hypercapnic exposure and may account for the inconsistencies seen in Fig. 3B.

It is also possible that the $\mathrm{CO}_{2}$ solubility constants and apparent pK values employed, derived from literature using Carcinus maenas and temperatureadjusted accordingly, are not entirely consistent with the actual blood chemistry of Chionoecetes tanneri. Such a discrepancy could be a function of altered hydrostatic pressure dynamics involved in working with deep-sea animals at ambient pressures, and could easily explain the minor differences in the $\Delta \mathrm{P}_{\mathrm{CO}_{2}}$ profiles observed between the 2 species.

The key point, however, is that Dungeness crabs were able to effectively regulate their hemolymph acid-base status despite an apparent higher internal $\mathrm{CO}_{2}$ load than that observed in Tanner crabs.

In this study, acid-base status was monitored in the extracellular fluid for $24 \mathrm{~h}$ without measuring intracellular $\mathrm{pH}(\mathrm{pHi})$. There is evidence that aquatic crustaceans can regulate $\mathrm{pHi}$ independently of extracellular pH (pHe) (Henry \& Wheatly 1992, Wheatly \& Henry 1992), maintaining a constant pHi during hypercapnicinduced acidification of the extracellular fluid (Gaillard \& Malan 1983). The Chinese mitten crab Eriocheir sinenesis actually increased pHi during an extracellular acidosis, presumably via rapid exchange of acid-base equivalents between the intra- and extra-cellular compartments (Whiteley et al. 2001). While constancy of pHi in the face of marked acifidication of the extracellular compartment may have occurred in Chionoecetes tanneri exposed to hypercapnia, this strategy is one more typically associated with strong acid-base regulators native to highly variable environments. Therefore, we postulate that the intracellular $\mathrm{pH}$ of Chionoecetes tanneri is likely compromised as a consequence of uncompensated acidification of the extracellular compartment, though this is an area of research we are actively pursuing.

Regardless of the extent of pHi regulation, maintenance of pHe within fairly tight limits is critical to proper function of extracellular respiratory proteins, and consequently oxygen delivery to tissues (Wheatly \& Henry 1992). Using the Dungeness crab, Johansen et al. (1970) calculated a Bohr shift that would account for a $50 \%$ increase in the hemolymph $\mathrm{P}_{50}$ (hemolymph oxygen tension at which hemocyanin is half-saturated) following a 0.4 unit decrease in hemolymph $\mathrm{pH}$. A similar effect with Chionoecetes tanneri hemolymph would greatly reduce oxygen carrying capacity and subsequent delivery to respiring tissues.

The inability of Chionoecetes tanneri to substantially accumulate extracellular bicarbonate from the environment may also involve a poor bicarbonate retention capacity. Even in strong acid-base regulators, $\mathrm{pH}$ compensation by uptake of bicarbonate equivalents from the surrounding medium is limited by the amount of bicarbonate that can be retained in the extracellular fluid (Truchot 1979). Maintenance of elevated concentrations of extracellular bicarbonate requires, within the kidney, a commitment of a substantial fraction of energetically costly proton pumping in order to reabsorb valuable bicarbonate ions that would otherwise be lost in the urine (Truchot 1987). We are currently undertaking bicarbonate infusion studies with Chionoecetes tanneri to determine the extent to which poor acid-base regulation in Tanner crabs is a function of a limited ability to acquire, or to retain, bicarbonate.

Both the net acquisition of basic equivalents from seawater, and renal retention of bicarbonate in the urine, require energetically costly epithelial ion pumping. Net acid excretion (or net base accumulation) during hypercapnia may occur at the direct expense of metabolic ATP in the case of $\mathrm{H}^{+}$-ATPases pumping protons across epithelia, or indirectly in the case of electroneutral exchange via $\mathrm{Na}^{+} / \mathrm{H}^{+}$or $\mathrm{Cl}^{-} / \mathrm{HCO}_{3}{ }^{-}$antiporters (see Ahearn et al. 1999 for a review). In the latter case, electroneutral $\mathrm{Na}^{+} / \mathrm{H}^{+}$and $\mathrm{Cl}^{-} / \mathrm{HCO}_{3}{ }^{-}$exchange show clearly the close coupling of ionic, osmotic, and acid-base regulation, highlighting the importance of the primary epithelial ion pump, $\mathrm{Na}^{+}-$ $\mathrm{K}^{+}$-ATPase in correction of ion gradients disturbed by the necessity of hypercapnic acid-base regulation (Ahearn et al. 1999). Furthermore, in the case of decapod crustaceans, $\mathrm{Na}^{+} / \mathrm{H}^{+}$exchange is electrogenic $\left(2 \mathrm{Na}^{+} / \mathrm{H}^{+}\right)$, possibly requiring direct synergistic interaction with an ATP-dependent ion pump such as a vacuolar, or V-type, $\mathrm{H}^{+}$-ATPase (Kimura et al. 1994).

Branchial pumping of acid-base relevant ions to offset acid-base disturbances can be an energetically costly process, and one which may be limited in deepsea benthic crustaceans which have metabolic rates typically an order of magnitude lower than their shallow-living counterparts (Childress et al. 1990). Our results, showing that the sluggish deep-sea Tanner crab has limited short-term extracellular acid-base compensatory capacity following hypercapnia, support the theory (Seibel \& Walsh 2001, Childress \& Seibel 1998) that deep-sea animals will be particularly sensitive to hypercapnia. As indirect evidence that the acid-base regulatory capacity of deep-sea animals is maladaptive to severe acid-base disturbance due to lowered metabolic rates, short-term extracellular $\mathrm{pH}$ compensation, and extracellular bicarbonate accumulation, were moderately improved when Tanner crabs were held under conditions of high oxygen, essentially hyperoxic to their in situ conditions (Fig. 3).

In shallow-living decapod crustaceans, lactate buildup in the extracellular compartment increases hemocyanin oxygen affinity and acts as a metabolic signaling compound to increase oxygen consumption rate (Lallier \& Truchot 1989, De watcher et al. 1997, Bridges 
2001). Accordingly, lactate mobilization in Cancer magister during hypercapnia corresponds well with the need for upregulation of metabolically costly acid-base regulatory transport phenomena (Fig. 5B).

In Tanner crabs held in both oxygen levels, however, lactate was absent from the serum prior to, and throughout, the $24 \mathrm{~h}$ exposure period (Fig. 5B). This deviance of the serum lactate pattern of Chionoecetes tanneri from the typical pattern displayed by Cancer magister (Fig. 5B) and other shallow-living decapod crustaceans (Bridges 2001), suggests that Chionoecetes tanneri relies on another signaling molecule, such as urate or magnesium (Bridges 2001) to effect the appropriate metabolic response. Additionally, it is possible that Chionoecetes tanneri produces lactic acid intracellularly during hypercapnic stress, but does not release lactate from the tissue. Extracellular release of the proton accompanying lactate, however, would explain the metabolic acid component evident in the Davenport diagrams for Chionoecetes tanneri (Fig. 4B). The data points lying below the passive buffering line ( 1 to $4 \mathrm{~h}$ in Tanner crabs acclimated to high $\mathrm{O}_{2}$ and 1 to $24 \mathrm{~h}$ in Tanner crabs acclimated to low $\mathrm{O}_{2}$ ) indicate a combination of respiratory and metabolic acid input into the extracellular fluid. While the respiratory component is protons derived from hydrated $\mathrm{CO}_{2}$, the metabolic component could stem from lactic acid-derived protons, and future work in our laboratory will focus on tissue metabolic and acid-base analyses during hypercapnic exposure.

\section{CONCLUSIONS}

This report represents, to our knowledge, one of the first detailed investigations of acid-base regulatory patterns in a deep-sea animal. Under the carbon sequestration scenario, generally involving deposition of large amounts of liquid $\mathrm{CO}_{2}$ on the deep sea floor, short-term tolerance of high $\mathrm{CO}_{2}$ concentrations will be vital. Storage lakes of $\mathrm{CO}_{2}$ in the deep-sea benthos (Ohsumi 1993) will be accompanied by large local water $\mathrm{pH}$ excursions (Adams et al. 1997). In such cases, the $\sim 0.4$ unit drop in serum $\mathrm{pH}$ in Chionoecetes tanneri exposed to $1 \% \mathrm{CO}_{2}$ and simultaneously acclimated to low $\mathrm{O}_{2}$, over $24 \mathrm{~h}$ (Fig. 3A), supports the hypothesis that the consequences of large-scale $\mathrm{CO}_{2}$ sequestration will be physiologically challenging to deep-sea animals - at least in the short term.

Additionally, the data support the synergistic effects of hypoxia and hypercapnia (see Portner et al. 2004 for a review). Under laboratory conditions, oxygen limitation exacerbated extracellular hypercapnic-induced acidosis in the deep-sea Tanner crab. Practically, then, $\mathrm{CO}_{2}$ sequestration in an area of the deep-sea that is nat- urally hypoxic (such as the OMZ of the eastern Pacific) may have greater detrimental effect on deep-sea fauna.

Even in the absence of large-scale sequestration, elevated atmospheric $\mathrm{CO}_{2}$ is continually being absorbed by the world's oceans, resulting in a $\mathrm{pH}$ depression of approximately 0.1 units to date, with a projected additional 0.4 unit reduction by the year 2100 (Haugan \& Drange 1996, Caldeira \& Wickett 2003, Glover \& Smith 2003, Sabine et al. 2004). This process of passive $\mathrm{CO}_{2}$ influx, left unabated for many years and combined with long-term turnover of deep ocean water, will eventually result in consistently hypercapnic conditions in the deep sea. Accordingly, chronic hypercapnic exposures are needed to understand how deep-sea animals will fare with such a challenge.

Acknowledgements. We gratefully acknowledge the talent and effort of the crews of the RV 'Point Lobos' and the ROV 'Ventana'. Additionally, we thank Patrick Whaling, Kurt Buck, Chris Lovera, Gernot Friederich, Eric Nelson, and Craig Okuda. These studies were supported by the Monterey Bay Aquarium Research Institute (Project 200002), the Ocean Carbon Sequestration Research Program, Biological and Environmental Research (BER), US Department of Energy (Award No. DEFG03-01DF63065 and DE-FG02-04ER63721), and the National Energy Technology Laboratory (NETL), US Department of Energy (Award No. DE-FC26-00NT40929).

\section{LITERATURE CITED}

Adams EE, Caulfield AJ, Herzog HJ, Auerbach DI (1997) Impacts of reduced $\mathrm{pH}$ from ocean $\mathrm{CO}_{2}$ disposal: sensitivity of zooplankton mortality to model parameters. Waste Manage 17:375-380

Ahearn GA, Duerr JM, Zhuang Z, Brown RJ, Aslamkhan A, Killebrew DA (1999) Ion transport processes of crustacean epithelial cells. Physiol Biochem Zool 72:1-18

Airriess CN, McMahon BR (1994) Cardiovascular adaptations enhance tolerance of environmental hypoxia in the crab Cancer magister. J Exp Biol 190:23-41

Barry JP, Buck KR, Lovera CL, Kuhnz L, Whaling PJ, Peltzer ET, Walz P, Brewer PG (2004) Effects of direct ocean $\mathrm{CO}_{2}$ injection on deep-sea meiofauna. J Oceanogr 60:759-766

Boutilier RG, Heming TA, Iwama GK (1984) Physiochemical parameters for use in fish respiratory physiology. In: Hoar WS, Randall DJ (eds) Fish physiology. Academic Press, London, $\mathrm{p}$ 403-430

Bradford MM (1976) A rapid and sensitive method for the quantitation of microgram quantities of protein utilizing the principle of protein-dye binding. Anal Biochem 72:248-254

Brewer PG, Peltzer ET, Friederich G, Aya I, Yamane K (2000) Experiments on the ocean sequestration of fossil fuel $\mathrm{CO}_{2}: \mathrm{pH}$ measurements and hydrate formation. Mar Chem 72:83-93

Bridges CR (2001) Modulation of haemocyanin oxygen affinity: properties and physiological implications in a changing world. J Exp Biol 204:1021-1032

Caldeira K, Wickett ME (2003) Anthropogenic carbon and ocean pH. Nature 425:365

Cameron JN (1978) Effects of hypercapnia on blood acid-base status, $\mathrm{NaCl}$ fluxes, and trans-gill potential in freshwater blue crabs, Callinectes sapidus. J Comp Physiol 123:137-141

Cameron JN (1985) Compensation of hypercapnic acidosis in the 
aquatic blue crab, Callinectes sapidus: the predominance of external seawater over carapace carbonate as the proton sink. J Exp Biol 114:197-206

Cameron JN (1986) Acid-base equilibria in invertebrates. In: Heisler $\mathrm{N}$ (ed) Acid-base regulation in animals. Elsevier, New York, p 357-394

Childress JJ (1995) Are there physiological and biochemical adaptations of metabolism in deep-sea animals? Trends Ecol Evol 10:30-36

Childress JJ, Seibel BA (1998) Life at stable low oxygen levels: adaptations of animals to oceanic oxygen minimum layers. J Exp Biol 201:1223-1232

Childress JJ, Cowles DL, Favuzzi JA, Mickel TJ (1990) Metabolic rates of benthic deep-sea decapod crustaceans decline with increasing depth primarily due to the decline in temperature. Deep-Sea Res 37:929-949

Claiborne JB, Heisler N (1986) Acid-base regulation and ion transfers in the carp (Cyprinus carpio): $\mathrm{pH}$ compensation during graded long- and short-term environmental hypercapnia, and the effect of bicarbonate infusion. J Exp Biol 126:41-61

Davenport HW (1974) The ABC of acid-base chemistry. University of Chicago Press, Chicago, IL

De Watcher B, Sartoris FJ, Portner HO (1997) The anaerobic endproduct lactate has a behavioural and metabolic signaling function in the shore crab Carcinus maenas. J Exp Biol 200:1015-1024

Dunn OJ (1964) Multiple contrasts using rank sums. Technometrics 6: 241-252

Edwards SL, Wall BP, Morrison-Shetlar A, Sligh S, Weakley JC, Claiborne JB (2005) The effect of environmental hypercapnia and salinity on the expression of NHE-like isoforms in the gills of a euryhaline fish (Fundulus heteroclitus). J Exp Zool 303A: $464-475$

Forgue J, Massabuau JC, Truchot JP (1992) When are resting water-breathers lacking $\mathrm{O}_{2}$ ? Arterial $\mathrm{P}_{\mathrm{O}_{2}}$ at the anaerobic threshold in crab. Resp Physiol 88:247-256

Friederich GE, Walz PM, Burczynski MG, Chavez FP (2002) Inorganic carbon in the central California upwelling system during the 1997-1999 El Niño-La Niña event. Prog Oceanogr 54:185-203

Gage JD, Tyler PA (1991) Deep-sea biology - a natural history of organisms at the deep-sea floor. Cambridge University Press, Cambridge

Gaillard S, Malan A (1983) Intracellular $\mathrm{pH}$ regulation in response to ambient hyperoxia or hypercapnia in the crayfish. Mol Physiol 4:231-243

Glover AG, Smith CR (2003) The deep-sea floor ecosystem: current status and prospects of anthropogenic change by the year 2025. Environ Conserv 30:219-241

Haugan PM, Drange H (1996) Effects of $\mathrm{CO}_{2}$ on the ocean environment. Energy Convers Manage 37:1019-1022

Henry RP, Wheatly MG (1992) Interaction of respiration, ion regulation, and acid-base balance in the everyday life of aquatic crustaceans. Am Zool 32:407-416

Henry RP, Perry HM, Trigg CB, Handley HL, Krarup A (1990) Physiology of two species of deep-water crabs, Chaceon fenneri and C. quinquedens: gill morphology, and hemolymph ionic and nitrogen concentrations. J Crustac Biol 10:375-381

Johansen K, Lenfant C, Mecklenburg TA (1970) Respiration in the crab, Cancer magister. Z Vgl Physiol 70:1-19

Kennett JP, Ingram BL (1995) A 20,000-year record of ocean circulation and climate change from the Santa Barbara basin. Nature 377:510-514

Kimura C, Ahearn GA, Busquets-Turner L, Haley SR, Nagao C, De Couet HG (1994) Immunolocalization of an antigen asso-

Editorial responsibility: Howard Browman (Associate Editorin-Chief), Storebø, Norway ciated with the invertebrate electrogenic $2 \mathrm{Na}^{+} / 1 \mathrm{H}^{+}$antiporter J Exp Biol 189:89-104

Lallier F, Truchot JP (1989) Hemolymph oxygen transport during environmental hypoxia in the shore crab, Carcinus maenas. Resp Physiol 77:323-336

Lang MA, Gainer H (1969) Isosmotic intracellular regulation as a mechanism of volume control in crab muscle fibers. Comp Biochem Physiol 30:445-456

Langenbuch M, Portner HO (2002) Changes in metabolic rate and $\mathrm{N}$ excretion in the marine invertebrate Sipunculus nudus under conditions of environmental hypercapnia: identifying effective acid-base variables. J Exp Biol 205:1153-1160

Marchetti $\mathrm{C}$ (1977) On geoengineering and the $\mathrm{CO}_{2}$ problem. Clim Change 1:59-68

Marchetti C (1979) Constructive solutions to the $\mathrm{CO}_{2}$ problem. In: Bach W, Pankrath J, Kellogg W (eds) Man's impact on climate. Elsevier Science, Amsterdam, p 299-311

Morris RH, Abbott DP, Haderlie EC (1980) Intertidal invertebrates of California. Stanford University Press, Stanford, CA

Ohsumi T (1993) Prediction of solute carbon dioxide behaviour around a liquid carbon dioxide pool on deep ocean basins. Energy Convers Manage 34:1059-1064

Portner HO, Langenbuch M, Reipschlager A (2004) Biological impact of elevated ocean $\mathrm{CO}_{2}$ concentrations: lessons from animal physiology and earth history. J Oceanogr 60:705-718

Sabine CL, Feely RA, Gruber N, Key RM and 11 others (2004) The ocean sink for anthropogenic $\mathrm{CO}_{2}$. Science 305:367-371

Seibel BA, Walsh PJ (2001) Potential impacts of $\mathrm{CO}_{2}$ injection on deep-sea biota. Science 294:319-320

Seibel BA, Thuesen EV, Childress JJ, Gorodezky LA (1997) Decline in pelagic cephalopod metabolism with habitat depth reflects differences in locomotory efficiency. Biol Bull 192: 262-278

Tamburri MN, Peltzer ET, Friederich GE, Aya I, Yamane K, Brewer PG (2000) A field study of the effects of $\mathrm{CO}_{2}$ ocean disposal on mobile deep-sea animals. Mar Chem 72:95-101

Toews DP, Holeton GF, Heisler N (1983) Regulation of the acid-base status during environmental hypercapnia in the marine teleost fish Conger conger. J Exp Biol 107:9-20

Truchot JP (1976) Carbon dioxide combining properties of the blood of the shore crab Carcinus maenas (L.): carbon dioxide solubility coefficient and carbonic acid dissociation constants. J Exp Biol 64:45-57

Truchot JP (1979) Mechanisms of the compensation of blood respiratory acid-base disturbances in the shore crab, Carcinus maenas (L.). J Exp Zool 210:407-416

Truchot JP (1984) Water carbonate alkalinity as a determinant of hemolymph acid-base balance in the shore crab, Carcinus maenas: a study at two different ambient $\mathrm{P}_{\mathrm{CO}_{2}}$ and $\mathrm{P}_{\mathrm{O}_{2}}$ levels. J Comp Physiol B 154:601-606

Truchot JP (1987) Comparative aspects of extracellular acidbase balance. Springer-Verlag, Berlin

Walsh PJ, Henry RP (1990) Activities of metabolic enzymes in the deep-water crabs Chaceon fenneri and C. quinquedens and the shallow-water crab Callinectes sapidus. Mar Biol 106: 343-346

Wheatly MG, Henry RP (1992) Extracellular and intracellular acid-base regulation in crustaceans. J Exp Zool 262:127-142

Whiteley NM, Scott JL, Breeze SJ, McCann L (2001) Effects of water salinity on acid-base balance in decapod crustaceans. J Exp Biol 204:1003-1011

Wyrtki K (1962) The oxygen minima in relation to ocean circulation. Deep-Sea Res 9:11-23

Zar JH (1984) Biostatistical analysis. Prentice-Hall, Englewood Cliffs, NJ

Submitted: October 10, 2006; Accepted: February 15, 2007

Proofs received from author(s): March 7, 2007 